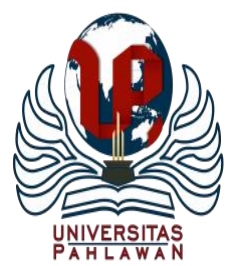

Jurnal Abdidas Volume 2 Nomor 1 Tahun 2021 Halaman 16-21

JURNAL ABDIDAS

http://abdidas.org/index.php/abdidas

\title{
Penyuluhan dan Sosialisasi Adab Bersin dan Batuk yang Baik dan Benar pada Siswa dan Guru Paud As-Syifa Tegal Bogor
}

\author{
In Rahmi Fatria Fajar ${ }^{1 \bowtie}$, Dewi Rahma Fitri ${ }^{2}$, Iin Hardiyati ${ }^{3}$ \\ Institut Sains dan Teknologi Alkamal, Jakarta, Indonesia ${ }^{1,2,3}$ \\ E-mail : Inrahmi14@gmail.com ${ }^{1}$, dewirahmafitri@gmail.com² , iin83hardiyati@gmail.com ${ }^{3}$
}

\begin{abstract}
Abstrak
Anak-anak sangat rentan terkena batuk dan pilek. Hal ini karena bakteri dan virus dapat terbang bebas setiap kali ada yang tidak menutup mulut dan hidung pada saat bersin maupun batuk. Adab batuk sangat diperuntukkan bagi yang sedang mengalami batuk atau bersin sehingga dapat meminimalisir terjadinya penularan penyakit terutama batuk. Tujuan kegiatan ini untuk memberi pemahaman dan pengetahuan mengenai adab bersin dan batuk yang baik dan benar serta perubahan sikap dan perilaku sebagai tindakan preventif kesehatan kepada masyarakat khususnya siswa/i dan guru PAUD. Observasi dilakukan untuk mengidentifikasi kondisi masyarakat di Desa Tegal, Bogor Jawa Barat. Hasil yang didapat dari kegiatan ini adalah siswa/i PAUD dan guru mendapatkan informasi kesehatan mengenai adab bersin dan batuk yang baik dan benar dan dapat meningkatkan kepedulian terhadap kesehatan serta meningkatnya perilaku hidup sehat dengan menjaga kebersihan diri dan lingkungan. Kesimpulan siswa/i dan guru PAUD dapat melakukan tindakan pencegahan penyakit menular dan meningkatkan derajat kesehatan menjadi lebih baik.
\end{abstract}

Kata kunci: adab, batuk, bersin, pencegahan, kesehatan

\section{Abstract}

Children are especially vulnerable to coughs and colds. This is because bacteria and viruses can fly freely whenever someone does not cover their mouth and nose when sneezing or coughing. Cough etiquette is intended for those who are experiencing coughs or sneezes so that it can minimize the occurrence of disease transmission, especially coughs. The purpose of this activity is to provide understanding and knowledge about proper and correct sneezing and coughing manners as well as changes in attitudes and behavior as a preventive measure for health to the community, especially students and teachers. Observations were made to identify the condition of the community in Tegal Village, Bogor, West Java. The results obtained from this activity are that students and teachers get good and correct health information about sneezing and coughing manners and can increase awareness of health and increase healthy behavior by maintaining personal hygiene and the environment. Conclusion: the students and teachers can take preventive measures for infectious diseases and improve their health status for the better.

Keyword: ethics, coughing, sneezing, prevention, health

Copyright (c) 2021 In Rahmi Fatria Fajar, Dewi Rahma Fitri, Iin Hardiyati

$\square$ Corresponding author

Address : Institut Sains Dan Teknologi Alkamal, Jakarta

Email : Inrahmi14@gmail.com

ISSN 2721- 9224 (Media Cetak)

DOI $\quad:$ https://doi.org/10.31004/abdidas.v2i1.193

ISSN 2721- 9216 (Media Online) 


\section{PENDAHULUAN}

Batuk merupakan aktifitas pengeluaran volume udara yang dilakukan secara refleks berasal dari rongga toraks dan keluar melalui epiglottis dan mulut. Aktifitas tersebut mengeluarkan aliran udara dan secara bersamaan mengeluarkan material yang ada pada saluran pernapasan termasuk di dalamnya sputum, bakteri maupun virus (Chung \& Widdicombe, 2018). Gangguan klinis yang paling banyak mencari bantuan medis salah satunya adalah batuk (De Jongste \& Shields, 2003). Gangguan yang terjadi pada penderita batuk diantaranya kelelahan, sulit tidur, suara serak, nyeri pada otot dan tulang, keluar keringat berlebih, dan dapat mengakibatkan keluarnya air urine (mengompol) (Setyanto, 2016).

Komplikasi batuk dapat terjadi hampir di semua sistem organ akibat adanya pelepasan tekanan udara tinggi pada intratorakal (Setyanto, 2016). Pada anak-anak batuk yang berlangsung terus-menerus dapat menganggu aktifitas sehingga menjadi tidak maksimal seperti kegiatan belajar, berkurangnya nafsu makan sampai terganggunya proses tumbuh kembang. Pada orang tua batuk yang sering terjadi dan terasa berat terutama terjadi pada malam hari.

Batuk merupakan bentuk pertahanan respiratorik, dimana dapat digunakan untuk membersihkan jalan napas dari mukus sekresi, pada orang dewasa mencapai $30 \mathrm{ml} /$ hari (Chung \& Widdicombe, 2018). Studi menyebutkan batuk pada anak umur 10 tahun sebagian besar terjadi pada siang hari dan biasanya batuk terjadi sampai 10x dalam waktu 24 jam (Irwin \& Madison, 2000). Angka ini dapat meningkat apabila terjadi infeksi respiratorik, peningkatan dapat terjadi pada anak sehat hingga 8x lipat. Walau sebagian besar batuk pada anak bukan karena kelainan paru yg serius, namun batuk yang terjadi sulit untuk diatasi dan sangat menganggu. Sampai batas tertentu batuk kronik mempunyai prognosis baik dan dinyatakan normal. Batuk dapat dinyatakan terdapat penyakit yang mendasarinya bila batuk yang terjadi sangat sering atau berat sehingga diperlukan penangganan khusus. (De Jongste \& Shields, 2003).

Aspek lingkungan dan aspek perilaku merupakan salah satu upaya pencegahan dan penularan batuk. Penelitian dari aspek perilaku pada pasien tuberkulosis menunjukkan angka $84 \%$ tidak menutup mulut dan hidung saat terjadi batuk maupun bersin dan $73,7 \%$ pembuangan dahak tidak sesuai dimana dahak tidak dibuang sesuai pada tempatnya (Marissa \& Nur, 2014).

Keadaan tersebut menunjukkan bahwa masyarakat seringkali bersikap acuh dan belum tanggap terhadap pencegahan penyakit serta belum menerapkan adab bersin dan batuk yang dapat berakibat pada penularan penyakit. Tiga aspek perbaikan yang dapat dilakukan untuk pencegahan penularan penyakit diantaranya adalah knowledge, perilaku dan tindakan masyarakat dalam menghadapi penyakit (Putri et al., 2013). Sehingga harus ada adab untuk mencegah penularan penyakit akibat droplet yang tersebar di udara. Adab bersin dan batuk merupakan salah satu perilaku yang ditujukan sebagai tindakan pencegahan penularan bibit penyakit melalui udara. Adab batuk dan bersin salah satu cara pencegahan penularan dengan cara memalingkan wajah dan apabila sedang terjadi bersin atau batuk 
akan segera menutup hidung dan mulut dengan sapu tangan apabila tidak terdapat sapu tangan maka mulut ataupun hidung dapat ditutup menggunakan tangan atau pangkal lengan (Indonesia, 2017).

Hasil penelitian mengenai respiratory hygiene pada masyarakat mengenai adab batuk menunjukan hanya $4,7 \%$ yang menerapkan adab batuk yang benar dan $64,4 \%$ masyarakat yang menerapkan perilaku menutup hidung dan mulut memakai tangan pada saat bersin serta $27,3 \%$ masyarakat yang tidak menutup mulut dan hidung saat batuk dan bersin (Barry et al., 2011).

Oleh sebab itu dinilai sangat perlu untuk melakukan kegiatan pengabdian masyarakat mengenai upaya promosi kesehatan mengenai penyuluhan dan sosialisasi adab bersin yang baik dan benar pada PAUD As-Syifa Tegal Bogor. Tujuan dari kegiatan penyuluhan dan sosialisasi ini adalah untuk meningkatkan pengetahuan masyarakat terutama siswa/i dan guru PAUD terhadap pencegahan dan pengendalian penularan penyakit melalui udara, upaya tindakan preventif dengan harapan mampu menerapkan dan mendampingi guru dan siswa/i PAUD terutama tentang bagaimana upaya mencegah penularan yang mungkin terjadi.

\section{METODE}

Pelaksanaan pengabdian masyarakat diawali dengan melakukan observasi untuk mengetahui kondisi yang terjadi pada Desa Tegal, Bogor-Jawa Barat. Pengumpulan informasi yang dibutuhkan untuk kegiatan dilakukan dengan menggunakan metode survei kepada tokoh masyarakat seperti
Ketua RT, Ketua RW, Kader Posyandu, dan Perwakilan warga setempat. Berdasarkan hasil observasi yang didapat dilakukan penyuluhan program dan sosialisasi mengenai kesehatan yang dapat membantu beberapa permasalahan yang ada pada Desa Tegal Bogor-Jawa Barat.

Program pengabdian yang diangkat ke masyarakat Desa Tegal Bogor-Jawa Barat adalah penyuluhan dan sosialisasi abad bersin dan batuk yang baik dan benar. Program ini dipilih agar diharapkan masyarakat khususnya siswa/i dan guru PAUD bertambah wawasan tentang cara pencegahan penularan penyakit khususnya batuk.

\section{HASIL DAN PEMBAHASAN}

Penerapan kegiatan ini dilakukan dengan kolaborasi antara dosen dan mahasiswa Institut Sains dan Teknologi Alkamal kepada masyarakat lingkungan PAUD As-Syifa Tegal Bogor. Penyuluhan dan sosialisasi ini menggunakan metode interaktif dan partisipatif melalui pemaparan materi terlebih dahulu, sesi demontrasi peragaan dan sesi terakhir dilakukan untuk sesi diskusi tanya jawab mengenai adab bersin dan batuk yang baik dan benar dan untuk melihat hasil dari perubahan perilaku untuk mencegah penularan penyakit.

Sasaran penyuluhan ini adalah siswa/i dan guru PAUD dengan tujuan umum untuk dapat meningkatkan pengetahuan dan pemahaman siswa/i tentang pentingnya adab bersin dan batuk dan perilaku hidup sehat. Disamping itu kegiatan ini memiliki tujuan khusus agar siswa/i mampu mengetahui dan memahami pentingnya cara pencegahan penularan batuk sejak usia dini. 
DOI: https://doi.org/10.31004/abdidas.v2i1.193

Kegiatan pertama dilakukan dengan pemaparan melalui ceramah mengenai adab bersin dan batuk dengan baik dan benar serta Cuci Tangan Pakai Sabun (CTPS). Untuk mempermudah penyampaian materi terhadap siswa/i menggunakan alat edukasi seperti brosur, laptop dan proyektor untuk penyampaian dan bingkisan untuk peserta yang aktif. Pada pemaparan materi diputar juga video tentang adab bersin dan batuk serta Cuci Tangan Pakai Sabun (CTPS) agar penyampaian materi lebih mendalam. Penyuluhan berjalan dengan tertib dan lancar tetapi pada saat pemberian materi menemui beberapa kendala seperti kesulitan penerimaan materi namun dapat diatasi dengan penggunaan kata ataupun kalimat yang lebih mudah dipahami oleh siswa/i PAUD.

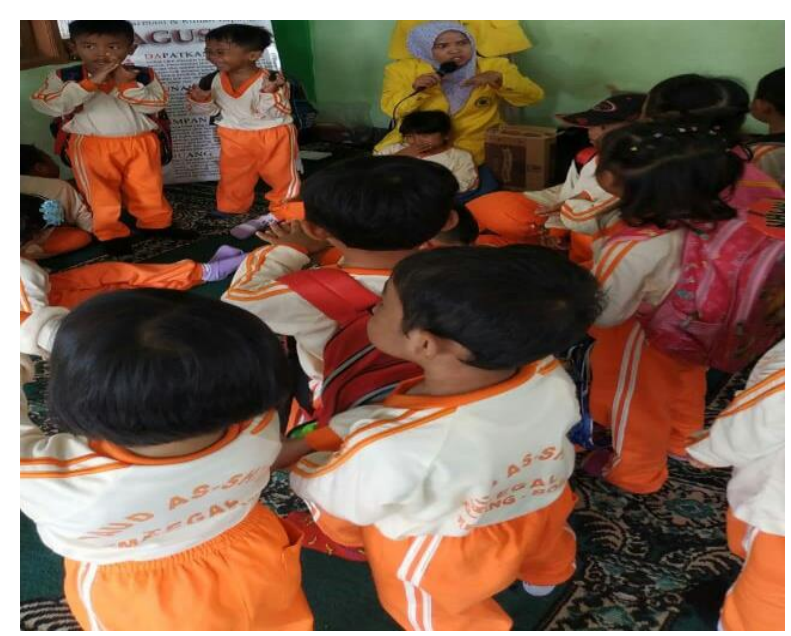

Gambar 1. Pemberian Materi Tentang Adab Bersin dan Batuk yang Baik dan Benar

Kemudian dilanjutkan partisipasi langsung masyarakat kepada siswa/i dan guru PAUD meliputi peragaan adab batuk dan bersin dengan benar, memperagakan Cuci Tangan Pakai Sabun (CTPS). Kegiatan dilakukan dengan perkelompok agar lebih merata dalam partisipasinya. Setiap anggota kelompok diarahkan menutup hidung dan juga mulut dengan sapu tangan saat bersin maupun batuk, menggunakan masker ataupun menggunakan lengan siku bagian dalam. Melakukan 7 langkah cuci tangan dengan sabun dengan air bersih yang mengalir mulai dari depan ke belakang tangan, sela-sela jari, buku-buku jari, kuku-kuku jari, jempol, pergelangan, serta membuang dahak di tempat yang benar.

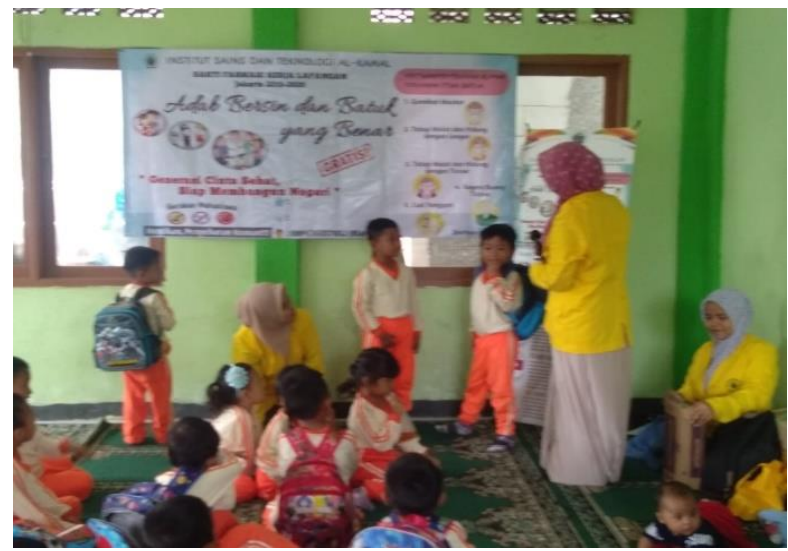

Gambar 2. Sesi Peragaan Kembali Adab Bersin dan Batuk oleh Siswa PAUD As-Syifa Tegal-

Bogor

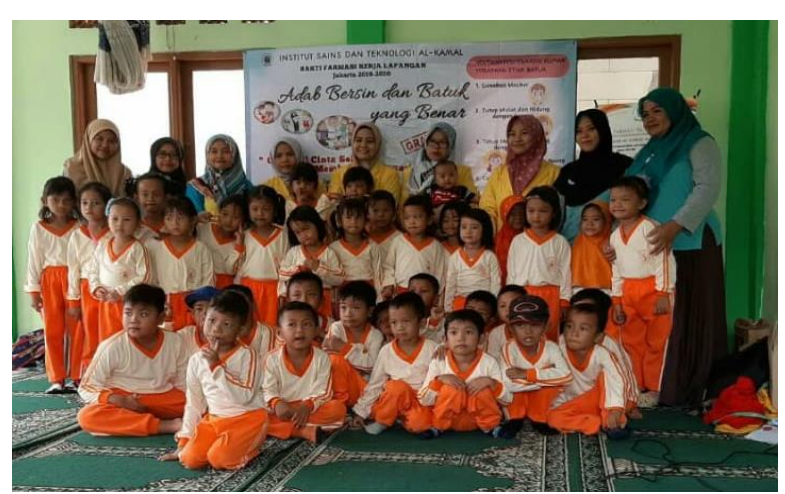

Gambar 3. Kegiatan Penyuluhan Seluruh Peserta Adab Bersin dan Batuk yang Baik dan Benar Kepada Siswa/i PAUD As-Syifa Tegal-Bogor

Kegiatan terakhir dari kegiatan penyuluhan ini adalah adalah sesi tanya jawab dan diskusi. 
Kegiatan ini dilakukan untuk memastikan bahwa setiap siswa/i PAUD pada khususnya dan guru PAUD memahami dan dapat mempraktekkan materi yang telah disampaikan. Penilaian keberhasilan dari program penyuluhan dan sosialisasi ini, dilakukan dengan meminta peserta untuk mengulang dan memperagakan kembali materi yang telah dijelaskan. Sesi diskusi dan tanya jawab dilakukan pada setiap siswa/i dan guru PAUD agar dapat mengetahui bahwa materi yang disampaikan dapat dipahami oleh seluruh peserta. Serta memberikan bingkisan sebagai hadiah kepada peserta penyuluhan agar lebih antusias dalam mengikuti kegiatan.

Hasil yang didapat dari kegiatan pengabdian ini adalah sebagai berikut :

1. Penyuluhan dan sosialisasi dilakukan langsung kepada siswa/i dan guru PAUD sehingga peserta dapat langsung mendapatkan pengetahuan kesehatan dan dapat meningkatkan kepedulian terhadap kesehatan dan lingkungan.

2. Meningkatnya pengetahuan siswa/i PAUD tentang pencegahan penularan batuk.

3. Meningkatkan pengetahuan guru PAUD untuk dapat mensosialisasikan hidup sehat.

4. Meningkatnya perilaku hidup bersih dan sehat .

5. Meningkatnya pengetahuan dan sikap siswa/i PAUD Kesehatan Lingkungan Hidup.

\section{SIMPULAN}

Pelaksanaan kegiatan pengabdian masyarakat di Desa Tegal, Bogor Jawa Barat berjalan dengan sangat baik sesuai target yang diharapkan. Hal ini dibuktikan dengan sikap antusias dalam penerimaan materi dan hasil pengulangan peragaan materi yang telah dikuasai oleh siswa/i PAUD dan guru PAUD. Kegiatan penyuluhan ini merupakan cara memberikan pemahaman, motivasi, edukasi, persuasi, promosi dan memberdayakan guru agar paham adab bersin dan batuk yang baik dan benar serta pencegahan penularan penyakit melalui udara.

\section{UCAPAN TERIMA KASIH}

Terima kasih Kami ucapkan kepada mahasiswa dan dosen yang telah memberikan waktu dan kontribusinya dalam kegiatan penyuluhan ini. Terima kasih pula Kami ucapkan kepada siswa/i dan guru PAUD As-Syifa sehingga kegiatan ini dapat berjalan sukses dan lancar.

\section{DAFTAR PUSTAKA}

Barry, T., Manning, S., Lee, M. S., Eggleton, R., Hampton, S., Kaur, J., Baker, M. G., \& Wilson, N. (2011). Respiratory hygiene practices by the public during the 2009 influenza pandemic: An observational study. Journal Influenza and other Respiratory Viruses, 5(5), 317-320.

Chung, K. F., \& Widdicombe, J. G. (2018). Cough: Causes, Mechanisms and Therapy. In Cough: Causes, Mechanisms and Therapy.

De Jongste, J. C., \& Shields, M. D. (2003). Cough $\cdot 2$ : Chronic cough in children. Thorax, 58(11), 998-1003.

Kementrian Kesehatan Republik Indonesia, (2017). Peraturan Menteri Kesehatan Republik Indonesia Nomor 27 tahun 2017 Tentang Pedoman Pencegahan Dan Pengendalian Infeksi Di Fasilitas Pelayanan Kesehatan (Vol. 4).

Irwin, R. S., \& Madison, J. M. (2000). The 
21 Penyuluhan dan Sosialisasi Adab Bersin dan Batuk yang Baik dan Benar pada Siswa dan Guru PAUD As-Syifa Tegal Bogor - In Rahmi Fatria Fajar, Dewi Rahma Fitri, Iin Hardiyati

DOI: https://doi.org/10.31004/abdidas.v2i1.193

Diagnosis and Treatment of Cough. New England Journal of Medicine, 343(23), $1715-1721$.

Marissa, N., \& Nur, A. (2014). Gambaran infeksi mycobacterium tuberculosis pada anggota rumah tangga pasien tb paru (Studi Kasus di Wilayah Kerja Puskesmas Darul Imarah Kabupaten Aceh Besar). Media Penelitian dan Pengembangan Kesehatan, 24(2), 89-94.

Putri, L. K., Karimi, J., \& Nugraha, D. P. (2013). Fakultas kedokteran universitas riau. Pedoman Penyelenggaran Pendidikan Fakultas Kedokteran Tahun Akademik 2014/2015, April, 1-9.

Setyanto, D. B. (2016). Batuk Kronik pada Anak: masalah dan tata laksana. Sari Pediatri, 6(2), 64. 